\title{
Winter floods in Britain are connected to atmospheric rivers
}

\author{
David A. Lavers, ${ }^{1,2}$ Richard P. Allan, ${ }^{2,3}$ Eric F. Wood, ${ }^{4}$ Gabriele Villarini, ${ }^{4,5}$ \\ David J. Brayshaw, ${ }^{2,3}$ and Andrew J. Wade ${ }^{1,6}$ \\ Received 23 September 2011; revised 26 October 2011; accepted 26 October 2011; published 6 December 2011.
}

[1] Damage from flooding in the winter and fall seasons has been widespread in the United Kingdom (UK) and Western Europe over recent decades. Here we show that winter flood events in the UK are connected to Atmospheric Rivers (ARs), narrow ribbons along which a large flux of moisture is transported from the subtropics to the mid-latitudes. Combining river flow records with rainfall measurements, satellite data and model simulations, we demonstrate that ARs occur simultaneously with the 10 largest winter flood events since 1970 in a range of British river basins, suggesting that ARs are persistently critical in explaining extreme winter flooding in the UK. Understanding the physical processes that determine the persistence of AR events will be of importance in assessing the risk of future flooding over north-western Europe and other mid-latitude regions. Citation: Lavers, D. A., R. P. Allan, E. F. Wood, G. Villarini, D. J. Brayshaw, and A. J. Wade (2011), Winter floods in Britain are connected to atmospheric rivers, Geophys. Res. Lett., 38, L23803, doi:10.1029/ $2011 \mathrm{GL} 049783$.

\section{Introduction}

[2] The warming of the Earth's climate is likely to result in an intensification of rainfall [Held and Soden, 2006; Allan and Soden, 2008; O'Gorman and Schneider, 2009] and anthropogenic climate change has already been linked with increased risk of damage associated with flooding during autumn 2000 that affected the UK and Western Europe [Kay et al., 2011; Pall et al., 2011]. The recent flood events of fall 2000 [Marsh and Dale, 2002], January 2003 [Marsh, 2004] and November 2009 [Hannaford, 2009] has highlighted the recurring and damaging nature of winter and fall UK flooding. Understanding the hydrometeorological processes responsible for flooding in UK river basins is therefore an important step in assessing the future risks of flooding over the UK and more generally mid-latitude regions.

[3] At any one time there are four or five narrow areas across the mid-latitudes (less than about $10 \%$ of the Earth's circumference) where approximately $90 \%$ of poleward atmospheric water vapour transport is concentrated [Zhu and

\footnotetext{
${ }^{1}$ Walker Institute, University of Reading, Reading, UK.

${ }^{2}$ Department of Meteorology, University of Reading, Reading, UK.

${ }^{3}$ National Centre for Atmospheric Science, University of Reading, Reading, UK.

${ }^{4}$ Department of Civil and Environmental Engineering, Princeton University, Princeton, New Jersey, USA.

${ }^{5}$ Willis Research Network, London, UK.

${ }^{6}$ Department of Geography and Environmental Science, University of Reading, Reading, UK.

Copyright 2011 by the American Geophysical Union. 0094-8276/11/2011GL049783
}

Newell, 1998]; because of the elongated nature of these regions they are known as atmospheric rivers (ARs) [Ralph et al., 2006] or moisture conveyor belts [Bao et al., 2006]. ARs are located in the lower troposphere within the warm sector of extra-tropical cyclones [Neiman et al., 2011] and are defined as areas of strong winds (greater than $12.5 \mathrm{~ms}^{-1}$ wind speed [Ralph and Dettinger, 2011]) with an Integrated Water Vapour (IWV) in the atmospheric column of more than $2 \mathrm{~cm}$ [Ralph et al., 2004]. The large amount of water vapour that is transported can lead to heavy precipitation and flooding when an AR makes landfall, especially if the moisture-laden air is forced to rise over mountains [Dettinger, 2011].

[4] Most AR research has focussed on the western USA, where an AR named the "Pineapple Express" occurs [Higgins et al., 2000; Dettinger, 2011]. ARs have been linked with floods on the Russian River in California [Ralph et al., 2006], flooding in the Pacific Northwest [Neiman et al., 2008a, 2011] and extreme snowfall in the Sierra Nevada [Guan et al., 2010]. Although ARs in the western USA cause flooding and destruction, the precipitation they deliver is vitally important for water resources in California [Dettinger et al., 2011]. ARs have also been successfully simulated in a regional climate model [Leung and Qian, 2009]. While the existence of ARs and tropical moisture export has been confirmed over the Atlantic Ocean [Knippertz and Wernli, 2010], they have previously only been linked to single heavy precipitation events in the Euro-Atlantic sector [Stohl et al., 2008; Knippertz and Wernli, 2010]. Here we show that ARs deliver moisture for the 10 largest winter flood events since 1970 in a range of British basins, and demonstrate that ARs are a critical mechanism in extreme winter floods in the UK (herein winter refers to the winter half-year, which spans October to March).

\section{Data and Methods}

[5] Across the UK there is a climatological precipitation gradient (western/north-western districts receive more precipitation than eastern/south-eastern regions due to the prevailing westerly winds and localised orographic enhancement of rainfall) and a variation in bedrock permeability (western regions are relatively impermeable leading to a rapid flow response, whereas the southeast has a slower response due to more permeable bedrock). The four river basins studied herein capture these main distinctive topographic, geological and precipitation regions of the UK (Figure 1). Daily river flows for the Eden at Temple Sowerby $\left(\right.$ area $\left.=616.4 \mathrm{~km}^{2}\right)$, Ewe at Poolewe $\left(441.1 \mathrm{~km}^{2}\right)$, Lambourn at Shaw $\left(234.1 \mathrm{~km}^{2}\right)$, and Teifi at Glan Teifi $\left(893.6 \mathrm{~km}^{2}\right)$ from 1 October 1970 to 30 September 2010 (40 UK water years; a UK water year typically begins on 1 October) were retrieved from the UK National River Flow Archive (NRFA). 


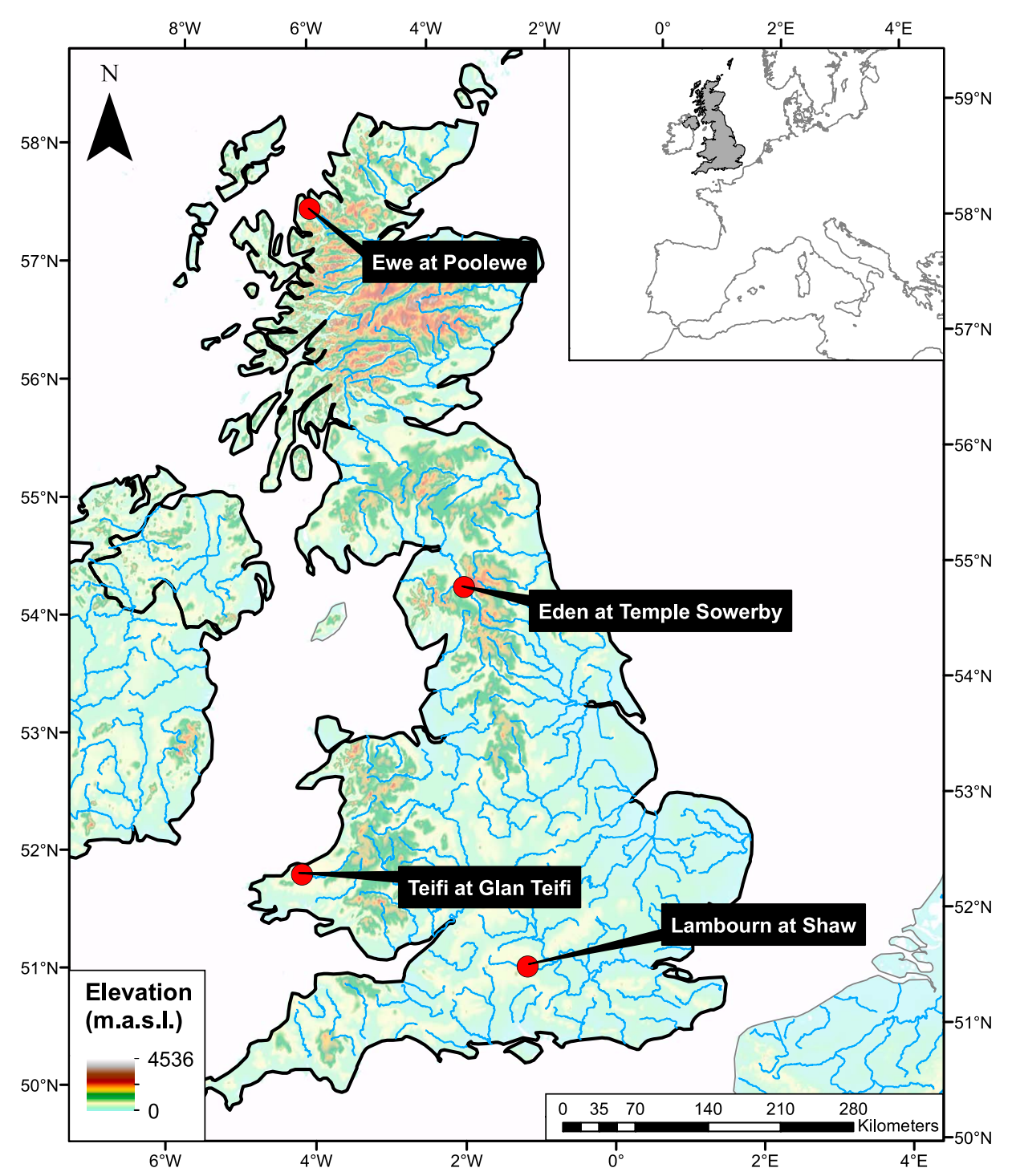

Figure 1. Map of the UK showing the location of the four river basins.

[6] To identify high flow events, the block maxima model was used for each winter half-year (October to March) over 1970-2010 to extract the largest daily mean river flow in each winter; hence this produced a Winter Maximum Series (WMS). This is an alternative form of the more common Annual Maximum Series used by Neiman et al. [2011]; our approach has the benefit of focussing on the winter high flow generating processes, as high summer rainfall and floods tend to be produced by a different mechanism, for example convective rainfall events. For the top 10 winter flood events in the four basins, we extracted precipitation for a local rain gauge (close to the river gauging station) from the UK Met Office Integrated Data Archive System (MIDAS) [Met Office, 2006].

[7] Specific humidity and zonal and meridional winds at $2^{\circ} \times 2^{\circ}$ resolution for $1970-2008$ were retrieved from the Twentieth Century Reanalysis Project [Compo et al., 2011] and for 2009 from the ERA-Interim dataset [Dee et al., 2011]. The satellite data (IWV, liquid cloud water and precipitation rate) were retrieved from the Special Sensor Microwave/ Imager and Sounder (SSMIS) instruments [Wentz and Spencer,
1998] (from www.ssmi.com). By employing linear regression between the satellite derived IWV and atmospheric reanalysis specific humidity we estimated that a specific humidity of $5 \mathrm{~g} \mathrm{~kg}^{-1}$ in winter is approximately equivalent to the $2 \mathrm{~cm}$ IWV threshold for AR classification [Ralph et al., 2004]. Note that an exploratory analysis found similar conclusions can be drawn when using the IWV or the specific humidity for AR identification.

[8] The top 10 winter river flows in the WMS in each basin were identified and the specific humidity and winds at $900 \mathrm{hPa}$ at $0600 \mathrm{UTC}$ on the day of the flood were analysed. Note that a comparison was made between the $900 \mathrm{hPa}$ specific humidity fields in the Twentieth Century and ERAInterim reanalyses and both datasets provided similar results. Also, the evolution of the specific humidity fields was evaluated to assess the persistence of the ARs for two days prior to the flood event and on the day of the event. To identify an AR's "axis" over the North Atlantic Ocean we firstly located at $0^{\circ} \mathrm{E}$ the latitude (between $40^{\circ} \mathrm{N}$ and $70^{\circ} \mathrm{N}$ ) where the maximum $900 \mathrm{hPa}$ specific humidity occurred. The axis of the AR was then identified by searching for the grid point 


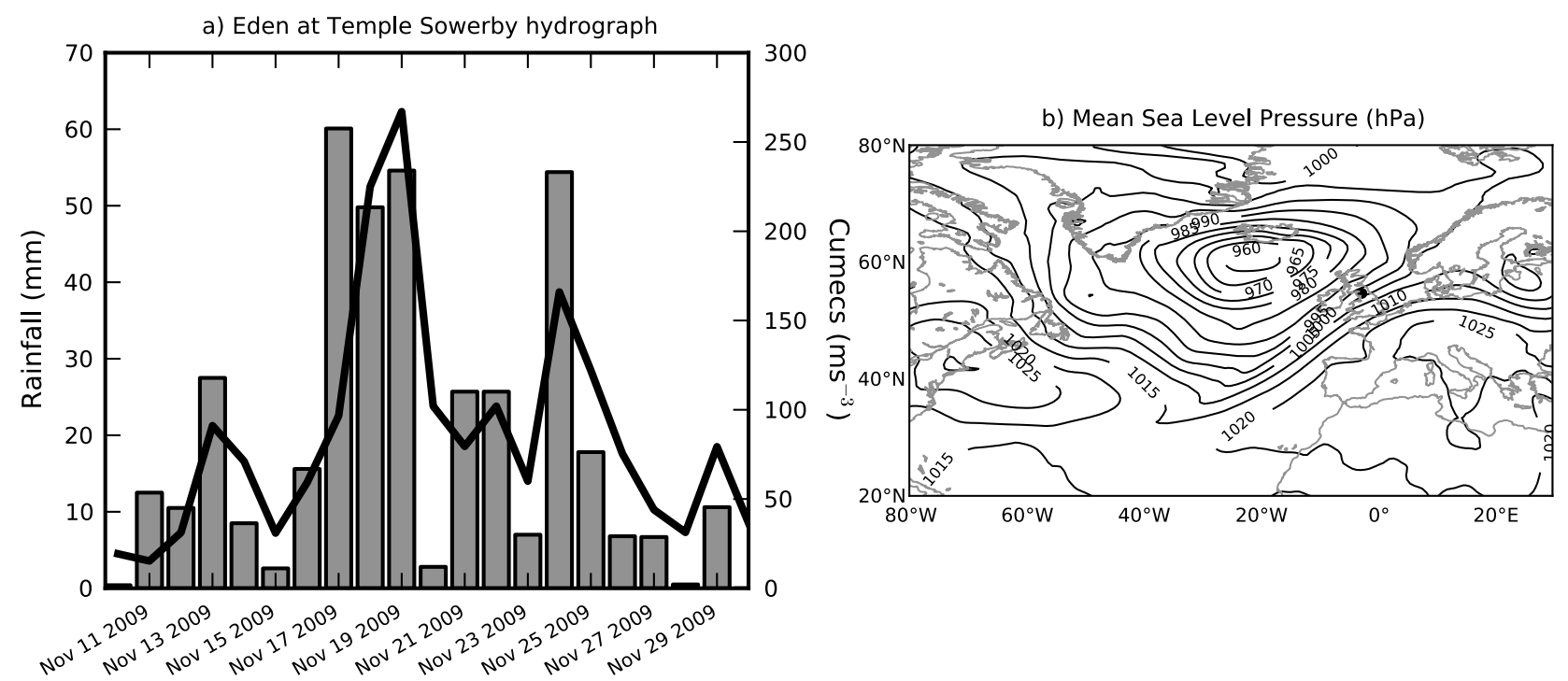

C) Specific humidity at $900 \mathrm{hPa}\left(\mathrm{g} \mathrm{kg}^{-1}\right)$

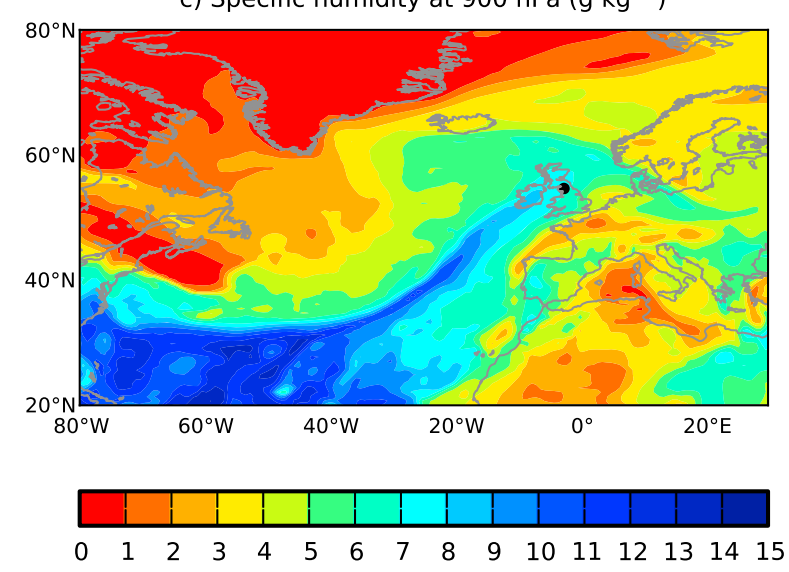

d) Vector wind at $900 \mathrm{hPa}\left(\mathrm{ms}^{-1}\right)$
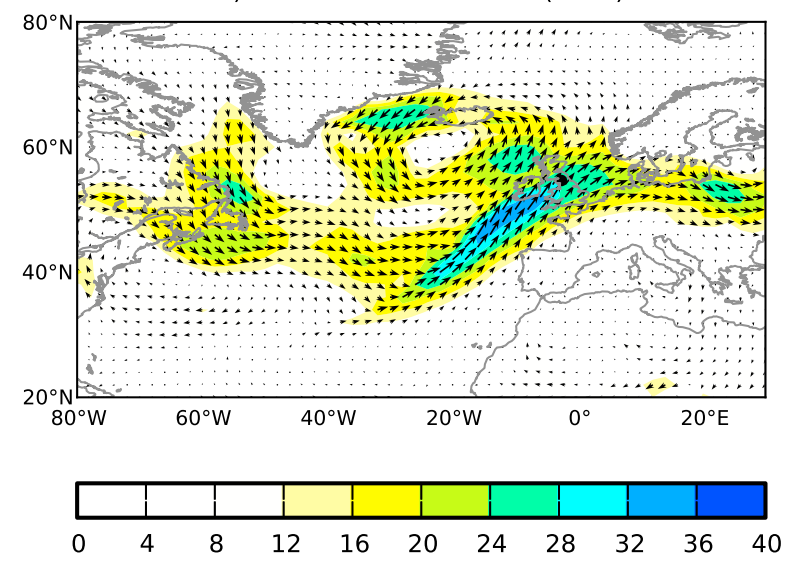

e) Atmospheric Water Vapour (cm)
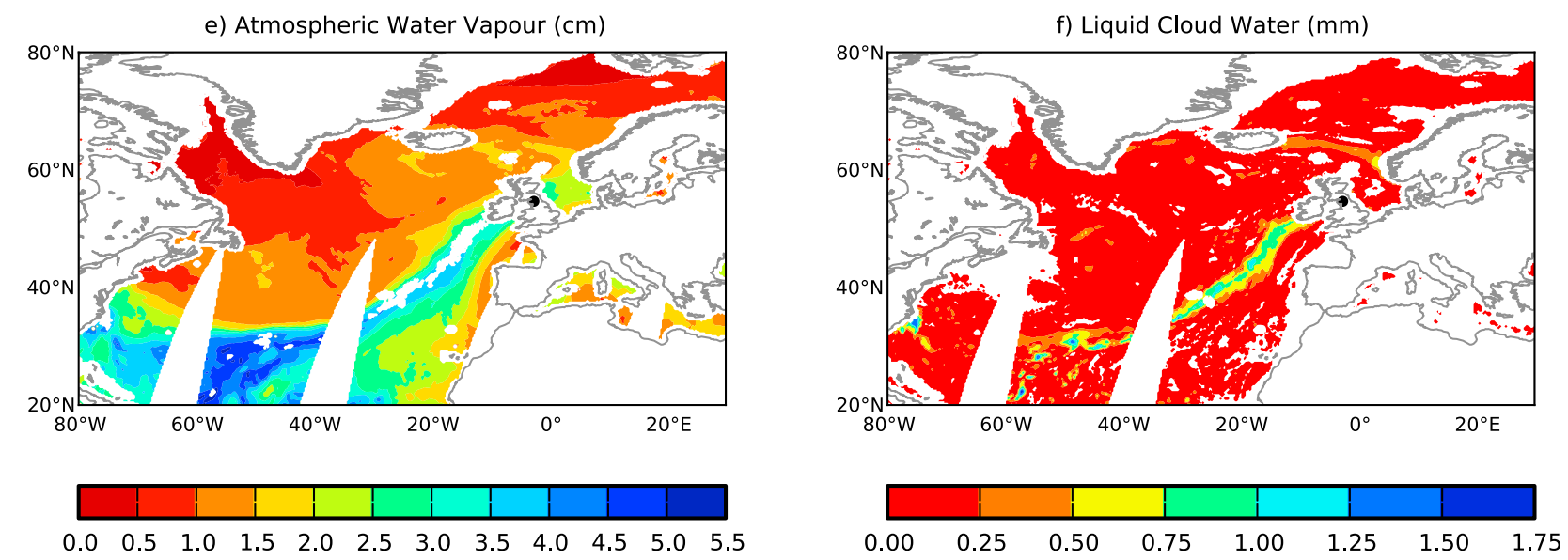

Figure 2. The 19th November 2009 flood event on the River Eden at Temple Sowerby (Cumbria): (a) the hydrograph of mean daily river flow (black line) and rainfall totals (grey bars); (b) the Mean Sea Level Pressure (MSLP) field (in hPa) at 0600 UTC on 19th November 2009; (c) the specific humidity at $900 \mathrm{hPa}$ (in $\mathrm{g} \mathrm{kg}^{-1}$ ) at $0600 \mathrm{UTC}$ on 19th November 2009; (d) the vector wind at $900 \mathrm{hPa}\left(\right.$ in $\mathrm{ms}^{-1}$ ) at 0600 UTC on 19th November 2009; SSMIS F16 retrievals of (e) column IWV (in $\mathrm{cm}$ ) and (f) Liquid Cloud Water (in mm). Note that the white colour in the centre of the AR in Figure 2e is missing values because the retrieval of water vapour fails in the presence of heavy rainfall. The black circle in Figures $2 \mathrm{~b}-2 \mathrm{f}$ marks the location of the River Eden at Temple Sowerby gauging station. 
(a) 07 January 2005

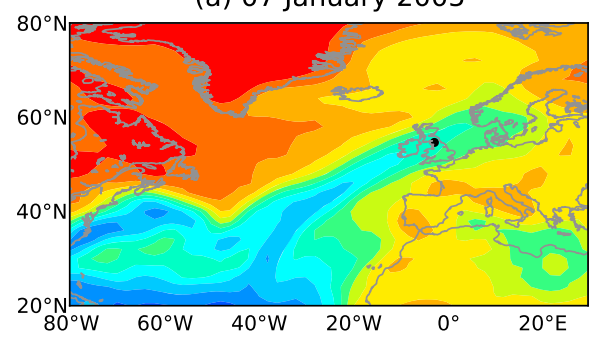

(b) 31 January 1995

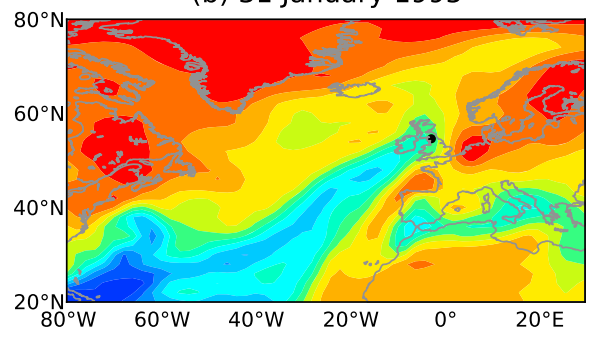

(c) 23 February 1991

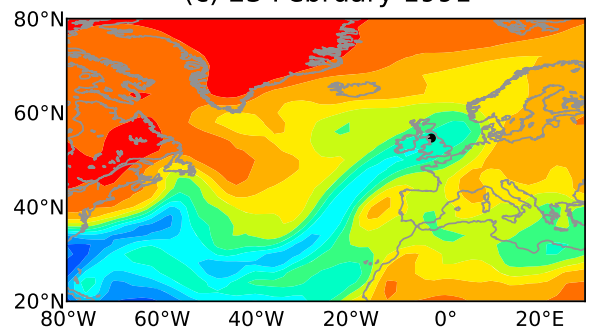

(d) 19 November 2009

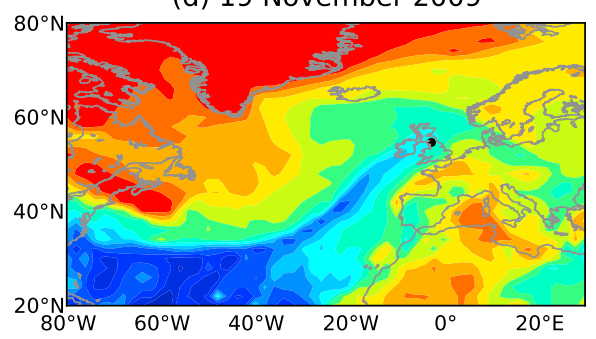

(e) 21 December 1985

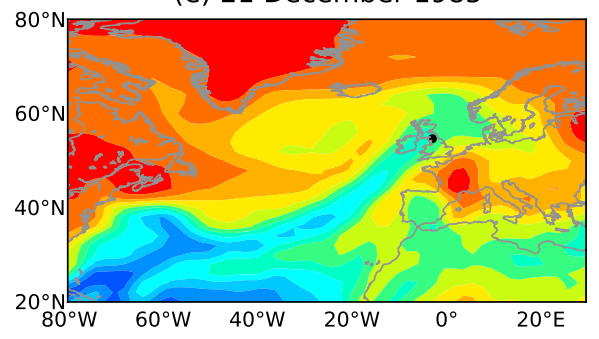

(f) 03 January 1982

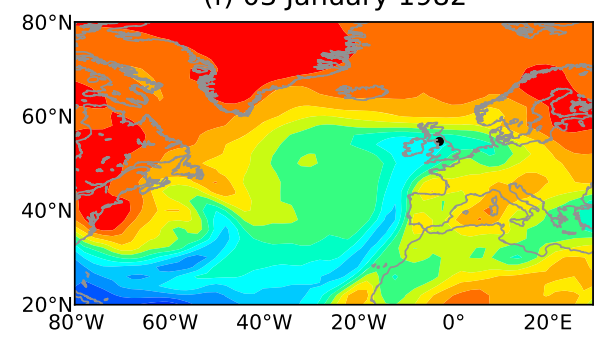

(g) 28 December 2007

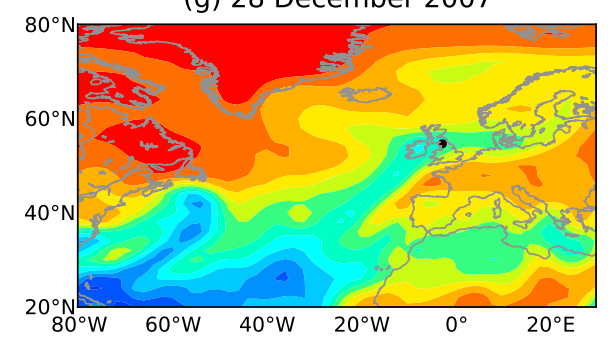

(h) 03 February 2004

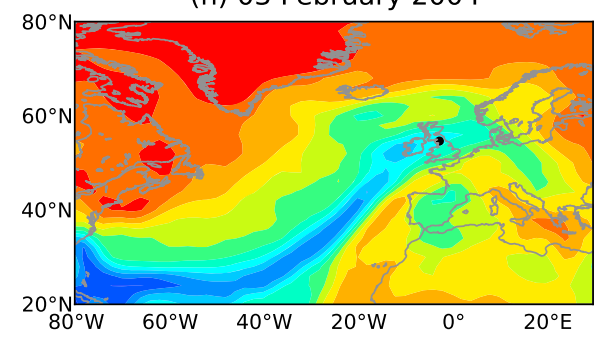

(i) 05 December 2006

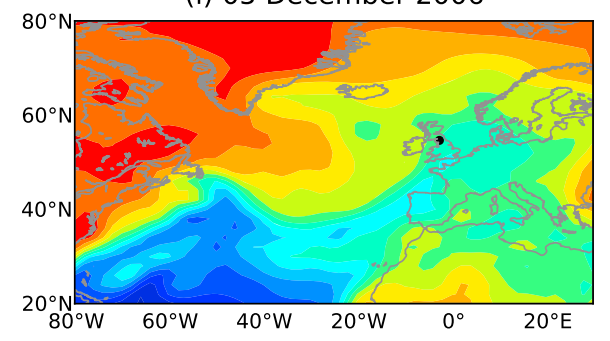

(j) 11 January 2009

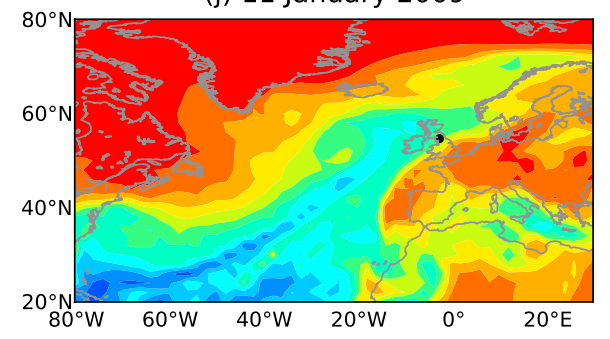

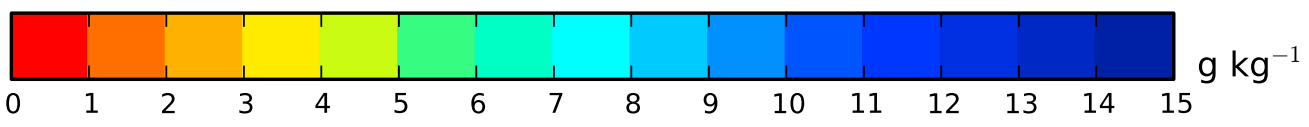

Figure 3. The $900 \mathrm{hPa}$ specific humidity fields at $0600 \mathrm{UTC}$ for $(\mathrm{a}-\mathrm{j})$ the top 10 winter flood events on the River Eden at Temple Sowerby. The black circle marks the location of the River Eden at Temple Sowerby gauging station.

next to $0^{\circ} \mathrm{E}$ (to the northwest/south/west) that had the highest specific humidity; the identified point was noted and the search was then repeated for the new grid point. This process was repeated until the "axis" left the geographical domain used. Loess (Locally weighted scatterplot smoothing) was used to produce a smooth AR "axis". Note that the term "axis" does not necessarily imply that it coincides with the trajectory of particular moist air parcels across the North Atlantic; the axes act as a simple diagnostic tool for showing the AR position and orientation. Five of the 40 identified ARs (10 ARs for each basin) required a slight manual 
a) Eden at Temple Sowerby

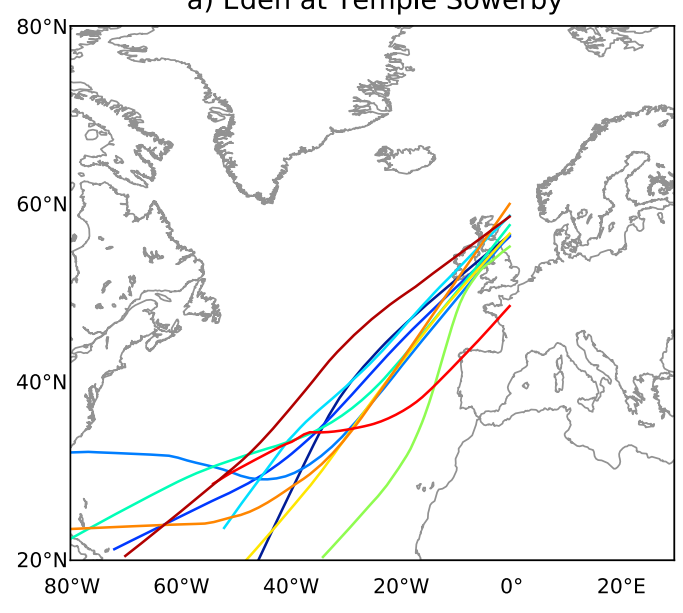

c) Teifi at Glan Teifi

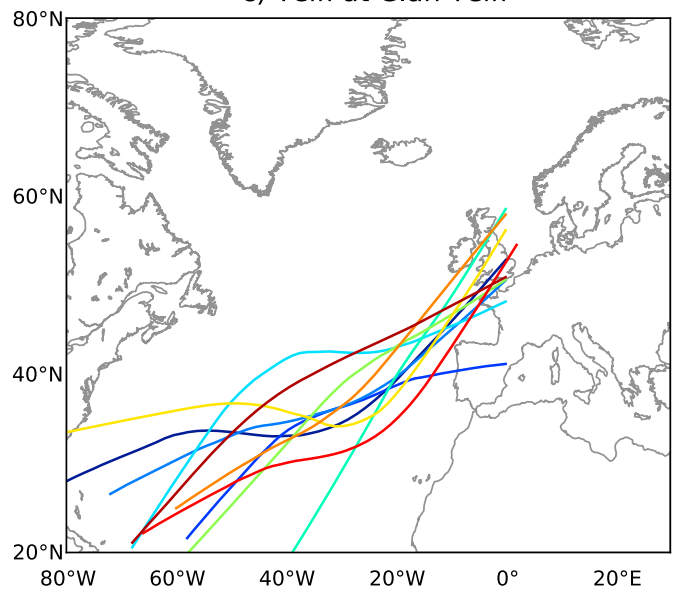

b) Ewe at Poolewe

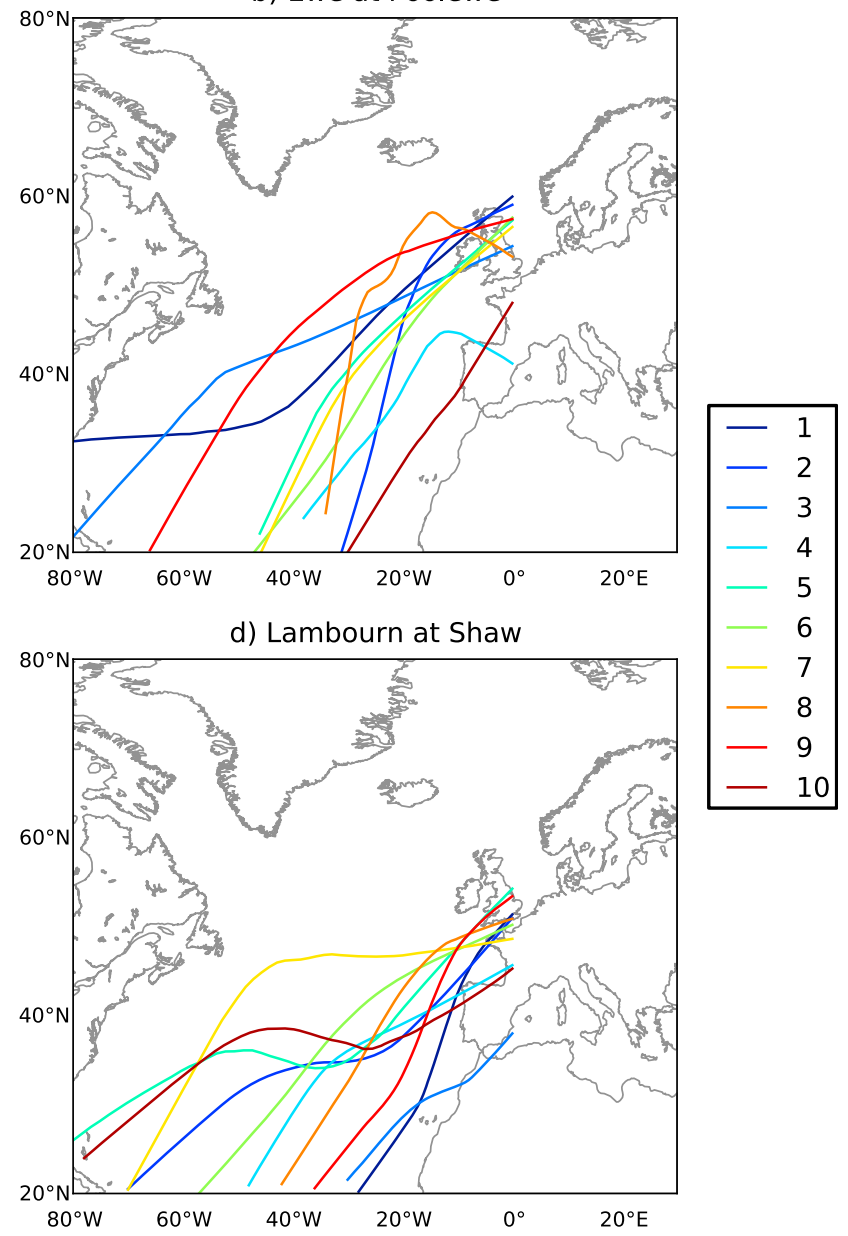

Figure 4. The AR locations at 0600 UTC for the top 10 winter flood events in the (a) Eden at Temple Sowerby, (b) Ewe at Poolewe, (c) Teifi at Glan Teifi, and (d) Lambourn at Shaw.

adjustment so that the resulting AR axis more closely resembled the path of the actual specific humidity maximum.

[9] Geopotential fields at $900 \mathrm{hPa}$ at $0600 \mathrm{UTC}$ for the top 10 winter floods in each basin were used in a composite analysis to evaluate the large-scale atmospheric circulation that occurred concurrently with the ARs. The $900 \mathrm{hPa}$ geopotential anomalies were calculated by averaging the geopotential at each grid point over the winter half-year for each of the top 10 winter floods. These 10 fields were then averaged to form a climatological $900 \mathrm{hPa}$ geopotential field from which the anomalies of the composite geopotential field at 0600 UTC on the day of the floods could be ascertained. This was repeated for the four basins.

\section{Results}

[10] In November 2009, the county of Cumbria (Northwest England) received record rainfall totals that led to severe flooding and devastation. On 19th November the River Eden at Temple Sowerby experienced flood conditions (with a mean daily flow of $267 \mathrm{~m}^{3} \mathrm{~s}^{-1}$; the fourth largest peak flow in the 40 year record) following a three day rainfall total of $164.5 \mathrm{~mm}$ (measured at a nearby rain gauge; Figure 2a). Basin soils were saturated, thus precluding further infiltration, in turn causing rapid runoff. On 19th November a deep low pressure $(957 \mathrm{hPa})$ was situated to the south of Iceland and relatively high pressure $(1029 \mathrm{hPa})$ was located over southern Europe (Figure 2b). This circulation pattern produced a south-westerly air flow over the British Isles (Figure 2d), associated with a plume of atmospheric moisture extending north-eastwards from the subtropics in the form of an AR as shown in the $900 \mathrm{hPa}$ specific humidity field at 0600 UTC on 19th November (Figure 2c). As this moisture ascended in the warm sector of the extra-tropical cyclone and was then forced to rise over the Cumbrian Mountains, it was precipitated out, thus producing the high rainfall totals and flooding observed. The presence of the AR is corroborated in the satellite imagery (SSMIS F16 satellite) of atmospheric water vapour (IWV; Figure 2e) and liquid cloud water (Figure 2f). The IWV $(>2 \mathrm{~cm})$ and wind speeds $\left(>12.5 \mathrm{~ms}^{-1}\right)$ exceed the thresholds used for defining ARs [Ralph et al., 2004; Ralph and Dettinger, 2011].

[11] The crucial role that ARs have in the occurrence of winter floods in the UK is highlighted by analysing the $900 \mathrm{hPa}$ specific humidity field at 0600 UTC on the day of the 10 largest winter flood events measured in the River Eden at Temple Sowerby basin since 1970 (Figure 3). Strikingly the top 10 winter floods are all accompanied by a plume of moisture with a similar shape and a southwest-northeast (SW-NE) orientation. This moisture is transported towards the UK by a south-westerly wind (e.g., Figure $2 d$ ) with both the large-scale ascent (in the warm sector) and orographic 
a) Eden at Temple Sowerby

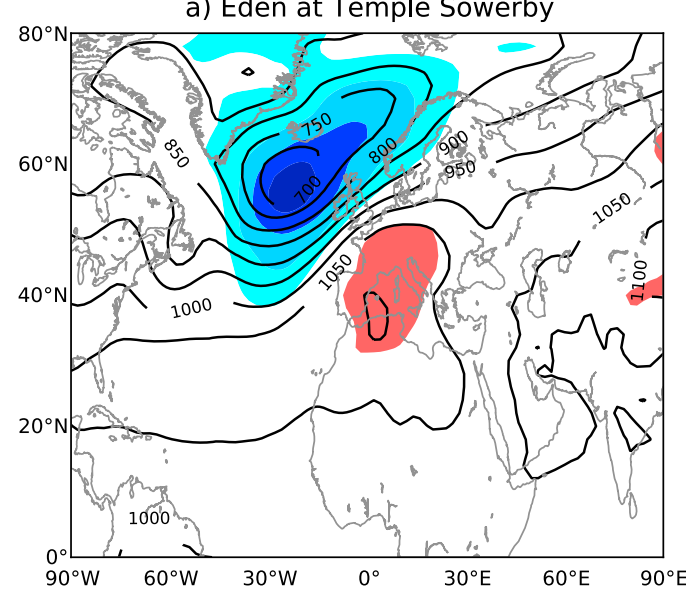

c) Teifi at Glan Teifi

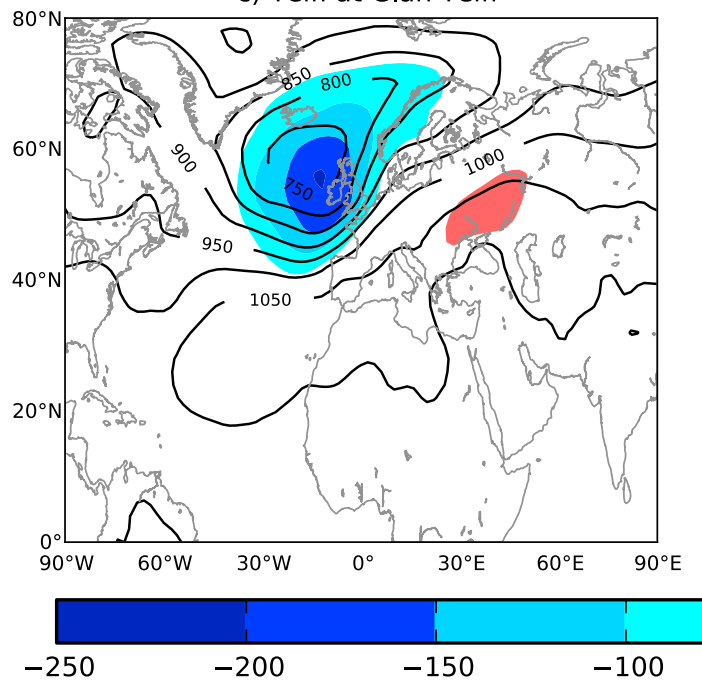

b) Ewe at Poolewe

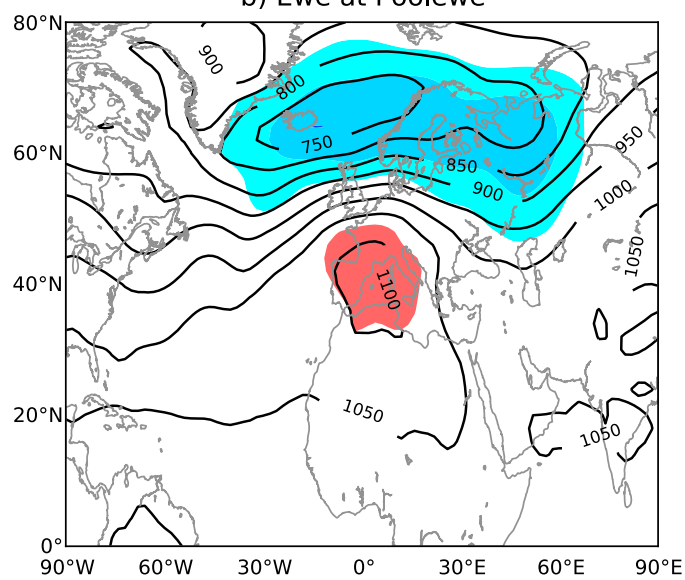

d) Lambourn at Shaw

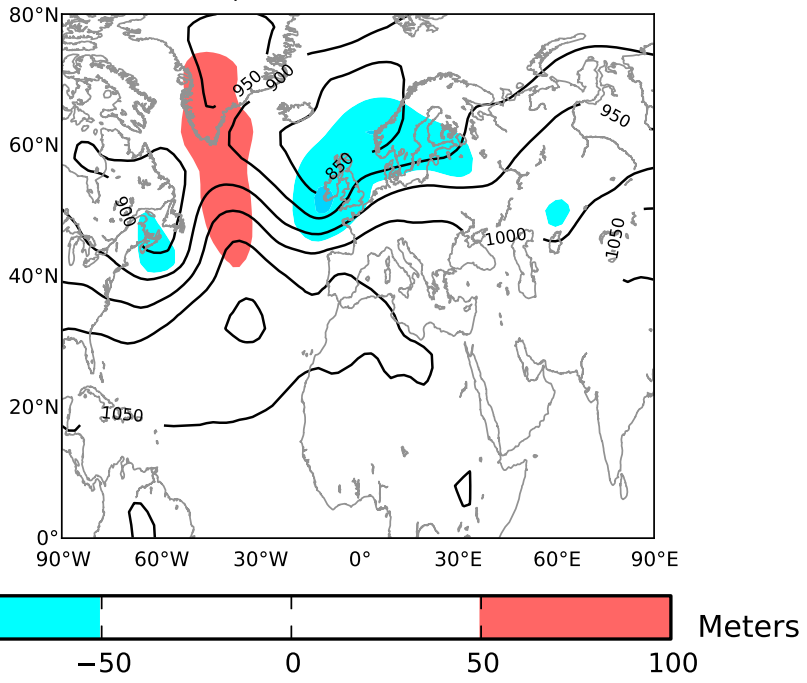

Figure 5. The composite mean of the Geopotential at $900 \mathrm{hPa}$ (in metres) at $0600 \mathrm{UTC}$ for the top 10 winter flood events in the (a) Eden at Temple Sowerby, (b) Ewe at Poolewe, (c) Teifi at Glan Teifi, and (d) Lambourn at Shaw. Red colours indicate positive geopotential anomalies; blue colours indicate negative geopotential anomalies.

uplift leading to the water vapour being precipitated out, and in turn producing high rainfall totals and floods. We estimate that in winter a specific humidity of $5 \mathrm{~g} \mathrm{~kg}^{-1}$ is approximately equivalent to the $2 \mathrm{~cm}$ IWV threshold, a criterion that the ARs in Figure 3 meet at points along their lengths. By inspection these ARs have an elongated shape, thus broadly confirming the AR criterion of being less than $1000 \mathrm{~km}$ wide and at least $2000 \mathrm{~km}$ long [Neiman et al., 2008b]. Interestingly smaller winter floods are not necessarily associated with an $\mathrm{AR}$ over the river basin indicating that ARs are drivers of the biggest winter flood events (Figure S1 in the auxiliary material). ${ }^{1}$

[12] Snapshots of the AR axes for the top 10 winter floods (at 0600 UTC on the day of the flood) are shown in Figure 4 for the four study basins. For all the basins the ARs tend to converge over the UK. For the Eden basin (Figure 4a) the ARs mainly lie directly over the basin as shown by the tight grouping of most of the top 10 events. In general the ARs for the Eden and Ewe basins (Figures $4 \mathrm{a}$ and $4 \mathrm{~b}$, respectively) have a more northerly position than the Teifi and Lambourn

${ }^{1}$ Auxiliary materials are available in the HTML. doi:10.1029/ 2011 GL049783. basins (Figures $4 \mathrm{c}$ and $4 \mathrm{~d}$, respectively) owing to the Eden and Ewe's location further north in the UK. The predominant SW-NE orientation of the ARs is also evident.

[13] The evolution of the $900 \mathrm{hPa}$ specific humidity field for three days (two days prior to the flood and on the day of the flood) up to the largest winter river flow in the Ewe basin (6th February 1989) again demonstrates the fundamental role ARs play in big winter flood events (Figure S2). Although the AR's location varies, the persistence of a SW-NE oriented AR is noticeable from the subtropical North Atlantic Ocean through Scotland to Scandinavia during the three day period. This led to a three day rainfall total of $242.7 \mathrm{~mm}$ (Table S2) and the highest river flow in the Ewe's record of 40 years $\left(227.1 \mathrm{~m}^{3} \mathrm{~s}^{-1}\right.$; Table S2). Further properties of the ARs influencing each basin are shown in Tables S1-S4.

[14] The composite mean of the large-scale $900 \mathrm{hPa}$ geopotential fields for the 10 largest winter floods in the four study basins is shown in Figure 5. For the Eden, Ewe and Teifi basins (Figures 5a-5c) the composite patterns have a trough of low geopotential situated to the northwest of Britain and a ridge of high geopotential located to the south/ southeast of Britain (over the Iberian Peninsula and western 
continental Europe). This pattern is associated with a tilt in the air flow and a south-westerly wind consistent with the poleward and upward advection of moisture-laden subtropical air in the warm sector of an extra-tropical cyclone to the south of Iceland. The location of the positive and negative anomalies in Figure $5 \mathrm{a}-5 \mathrm{c}$ caused a larger than normal $900 \mathrm{hPa}$ geopotential gradient during the top 10 winter floods consistent with a stronger south-westerly wind that transported water vapour as an AR towards the UK. The Lambourn basin (Figure 5d) has a somewhat different overall pattern, but a tilt is still clearly recognisable in the air flow over Western Europe with a weak trough (low geopotential) to the northwest of Britain and a weak ridge (high geopotential) over the northwest Mediterranean and southern Europe. Furthermore, as the Lambourn has a permeable bedrock, a flood event is generally caused by precipitation over a longer time period (approximately two months); this may explain the relatively low (compared to the other basins) three day rainfall totals (Table S4). Therefore, it will generally require a series of extratropical cyclones and their associated ARs to cause a flood in a permeable basin such as the Lambourn. In turn, an assessment of specific humidity and geopotential fields must consider the requisite basin response time between rainfall and flood.

\section{Discussion and Conclusions}

[15] While the presence of ARs in the Euro-Atlantic sector has been described previously, starting with a hydrological analysis, this is the first time in which ARs are shown to occur simultaneously and prior to the 10 largest winter flood events in a range of British river basins. The SW-NE tilt in the large-scale atmospheric flow associated with baroclinic wave activity is crucial, acting to advect moisture from the primary source region over the subtropical North Atlantic [Gimeno et al., 2010] poleward and eastward towards the UK causing high precipitation and flooding. Although it seems that in flood events herein the tropical North Atlantic is the source for the water vapour in ARs, back trajectory analysis would need to be employed to confirm a tropical origin [e.g., Bao et al., 2006; Stohl et al., 2008]. The occurrence of ARs with the biggest winter flood events and an absence of ARs over the river basins during the smallest winter floods suggest that the existence of a persistent AR is a precursor of the most extreme winter hydrological events. This uncovered connection between ARs and flooding provides the opportunity to assess the realism of climate model simulations and projections of the relevant large-scale processes behind winter flooding in the UK and Western Europe.

[16] There are two factors that could affect the impact that ARs have on future winter flooding events. Firstly a change in frequency of AR occurrence will affect the frequency of extreme winter flood events (especially in impermeable basins). This will depend on projected changes to the large-scale atmospheric circulation over the North Atlantic sector and its consequent impacts on baroclinic wave activity and extra-tropical cyclones, which are as yet highly uncertain [Ulbrich et al., 2009]. Furthermore, in a changing climate there could be changes in the low-altitude winds that could affect water vapour transport in ARs [Dettinger, 2011]. Secondly even if the frequency of ARs does not change, the atmospheric water vapour content in a warmer climate is likely to rise due to an increase in saturation water vapour pressure with air temperature, as governed by the ClausiusClapeyron equation [e.g., Held and Soden, 2006]. This is expected to lead to a change in the hydrological cycle and an enhancement of precipitation extremes [O'Gorman and Schneider, 2009], which could result in AR events delivering more precipitation and in turn a higher risk of larger winter floods. It is therefore essential to now undertake further detailed analysis on the atmospheric conditions in which ARs develop over the North Atlantic Ocean to evaluate how anthropogenic climate change may alter the atmospheric circulation and hence future AR events.

[17] Acknowledgments. We thank the UK Environment Agency and the UK National River Flow Archive, based at the Centre for Ecology and Hydrology in Wallingford, UK for kindly providing the daily river flow data. The work was funded by the UK Natural Environment Research Council under the Changing Water Cycle programme, HyDef project $(\mathrm{NE} / \mathrm{I} 00677 \mathrm{X} / 1)$. We also thank the two reviewers for their valuable comments.

[18] The Editor thanks the two anonymous reviewers for their assistance in evaluating this paper.

\section{References}

Allan, R. P., and B. J. Soden (2008), Atmospheric warming and the amplification of precipitation extremes, Science, 321(5895), 1481-1484, doi:10.1126/science. 1160787.

Bao, J. W., S. A. Michelson, P. J. Neiman, F. M. Ralph, and J. M. Wilczak (2006), Interpretation of enhanced integrated water vapor bands associated with extratropical cyclones: Their formation and connection to tropical moisture, Mon. Weather Rev., 134(4), 1063-1080, doi:10.1175/ MWR3123.1.

Compo, G. P., et al. (2011), The Twentieth Century Reanalysis project, Q. J. R. Meteorol. Soc., 137(654), 1-28, doi:10.1002/qj.776.

Dee, D. P., et al. (2011), The ERA-Interim reanalysis: Configuration and performance of the data assimilation system, Q. J. R. Meteorol. Soc., 137(656), 553-597, doi:10.1002/qj.828.

Dettinger, M. (2011), Climate change, atmospheric rivers, and floods in California-A multimodel analysis of storm frequency and magnitude changes, J. Am. Water Resour. Assoc., 47(3), 514-523, doi:10.1111/ j.1752-1688.2011.00546.x.

Dettinger, M. D., F. M. Ralph, T. Das, P. J. Neiman, and D. R. Cayan (2011), Atmospheric rivers, floods and the water resources of California, Water, 3, 445-478, doi:10.3390/w3020445.

Gimeno, L., A. Drummond, R. Nieto, R. M. Trigo, and A. Stohl (2010), On the origin of continental precipitation, Geophys. Res. Lett., 37, L13804, doi:10.1029/2010GL043712.

Guan, B., N. P. Molotch, D. E. Waliser, E. J. Fetzer, and P. J. Neiman (2010), Extreme snowfall events linked to atmospheric rivers and surface air temperature via satellite measurements, Geophys. Res. Lett., 37, L20401, doi:10.1029/2010GL044696.

Hannaford, J. (2009), UK Flooding - Briefing from the Centre for Ecology \& Hydrology, edited, Cent. for Ecol. and Hydrol., Wallingford, U. K.

Held, I. M., and B. J. Soden (2006), Robust responses of the hydrological cycle to global warming, J. Clim., 19(21), 5686-5699, doi:10.1175/ JCLI3990.1.

Higgins, R. W., J. K. E. Schemm, W. Shi, and A. Leetmaa (2000), Extreme precipitation events in the western United States related to tropical forcing, J. Clim., 13(4), 793-820, doi:10.1175/1520-0442(2000)013<0793: EPEITW $>2.0 . \mathrm{CO} ; 2$.

Kay, A. L., S. M. Crooks, P. Pall, and D. A. Stone (2011), Attribution of autumn/winter 2000 flood risk in England to anthropogenic climate change: A catchment-based study, J. Hydrol., 406, 97-112, doi:10.1016/ j.jhydrol.2011.06.006

Knippertz, P., and H. Wernli (2010), A Lagrangian climatology of tropical moisture exports to the Northern Hemispheric extratropics, J. Clim., 23(4), 987-1003, doi:10.1175/2009JCLI3333.1.

Leung, L. R., and Y. Qian (2009), Atmospheric rivers induced heavy precipitation and flooding in the western US simulated by the WRF regional climate model, Geophys. Res. Lett., 36, L03820, doi:10.1029/ 2008 GL036445.

Marsh, T. J. (2004), The January 2003 flood on the Thames, Weather, 59(3), 59-62, doi:10.1256/wea.212.03.

Marsh, T. J., and M. Dale (2002), The UK floods of 2000-2001: A hydrometeorological appraisal, Water Environ. J., 16(3), 180-188, doi:10.1111/ j.1747-6593.2002.tb00392.x. 
Met Office (2006), MIDAS Land Surface Stations data (1853-current), edited, NCAS Br. Atmos. Data Cent., Didcot, U. K.

Neiman, P. J., et al. (2008a), Diagnosis of an intense atmospheric river impacting the Pacific Northwest: Storm summary and offshore vertical structure observed with COSMIC satellite retrievals, Mon. Weather Rev., 136(11), 4398-4420, doi:10.1175/2008MWR2550.1.

Neiman, P. J., F. M. Ralph, G. A. Wick, J. D. Lundquist, and M. D. Dettinger (2008b), Meteorological characteristics and overland precipitation impacts of atmospheric rivers affecting the West Coast of North America based on eight years of SSM/I satellite observations, J. Hydrometeorol., 9(1), 22-47, doi:10.1175/2007JHM855.1.

Neiman, P. J., L. J. Schick, F. M. Ralph, M. Hughes, and G. A. Wick (2011), Flooding in western Washington: The connection to atmospheric rivers, J. Hydrometeorol., doi:10.1175/2011JHM1358.1, in press.

O'Gorman, P. A., and T. Schneider (2009), The physical basis for increases in precipitation extremes in simulations of 21 st-century climate change, Proc. Natl. Acad. Sci. U. S. A., 106(35), 14,773-14,777, doi:10.1073/ pnas.0907610106.

Pall, P., et al. (2011), Anthropogenic greenhouse gas contribution to flood risk in England and Wales in autumn 2000, Nature, 470(7334), 382-385, doi:10.1038/nature09762.

Ralph, F. M., and M. D. Dettinger (2011), Storms, floods, and the science of atmospheric rivers. Eos Trans. $A G U, 92(32), 265$, doi:10.1029/ $2011 \mathrm{EO} 320001$.

Ralph, F. M., P. J. Neiman, and G. A. Wick (2004), Satellite and CALJET aircraft observations of atmospheric rivers over the eastern North Pacific Ocean during the winter of 1997/98, Mon. Weather Rev., 132(7), 1721-1745, doi:10.1175/1520-0493(2004)132<1721:SACAOO>2.0.CO;2.

Ralph, F. M., P. J. Neiman, G. A. Wick, S. I. Gutman, M. D. Dettinger, D. R. Cayan, and A. B. White (2006), Flooding on California's
Russian River: Role of atmospheric rivers, Geophys. Res. Lett., 33, L13801, doi:10.1029/2006GL026689.

Stohl, A., C. Forster, and H. Sodemann (2008), Remote sources of water vapor forming precipitation on the Norwegian west coast at $60^{\circ} \mathrm{N}$ : A tale of hurricanes and an atmospheric river, J. Geophys. Res., 113, D05102, doi:10.1029/2007JD009006.

Ulbrich, U., G. C. Leckebusch, and J. G. Pinto (2009), Extra-tropical cyclones in the present and future climate: A review, Theor. Appl. Climatol., 96(1-2), 117-131, doi:10.1007/s00704-008-0083-8.

Wentz, F. J., and R. W. Spencer (1998), SSM/I rain retrievals within a unified all-weather ocean algorithm, J. Atmos. Sci., 55(9), 1613-1627, doi:10.1175/1520-0469(1998)055<1613:SIRRWA >2.0.CO;2.

Zhu, Y., and R. E. Newell (1998), A proposed algorithm for moisture fluxes from atmospheric rivers, Mon. Weather Rev., 126(3), 725-735, doi:10.1175/1520-0493(1998)126<0725:APAFMF>2.0.CO;2.

R. P. Allan and D. J. Brayshaw, Department of Meteorology, National Centre for Atmospheric Science, University of Reading, Earley Gate, Reading RG6 6BB, UK.

D. A. Lavers, Department of Meteorology, Walker Institute, University of Reading, Earley Gate, Reading RG6 6AR, UK. (d.a.lavers@reading.ac.uk) G. Villarini and E. F. Wood, Department of Civil and Environmental Engineering, Princeton University, Engineering Quadrangle, Princeton, NJ 08544, USA.

A. J. Wade, Department of Geography and Environmental Science, Walker Institute, University of Reading, Whiteknights, Reading RG6 $6 \mathrm{AB}, \mathrm{UK}$ 